\title{
In-Situ Gamma-PHA Measurements to Support Unconditional Release of 235-F Chiller Units
}

by

S. R. Salaymeh

Westinghouse Savannah River Company

Savannah River Site

Aiken, South Carolina 29808

R. A. Dewberry

J. D. Leyba

DOE Contract No. DE-AC09-96SR18500

This paper was prepared in connection with work done under the above contract number with the U.S. Department of Energy. By acceptance of this paper, the publisher and/or recipient acknowledges the U.S. Government's right to retain a nonexclusive, royalty-free license in and to any copyright covering this paper, along with the right to reproduce and to authorize others to reproduce all or part of the copyrighted paper. 
WSRC-TR-2000-00013

Revision 0

\title{
In-Situ $\gamma$-PHA Measurements
}

\section{To Support Unconditional Release of 235-F Chiller Units (U)}

\author{
Saleem R. Salaymeh,
}

Raymond A. Dewberry,

And

John D. Leyba

Unclassified

Does Not Contain Unclassified Controlled Nuclear Information (UCND)

January 13,2000

Westinghouse Savannah River Company

Savannah River Site

Aiken, SC 29808

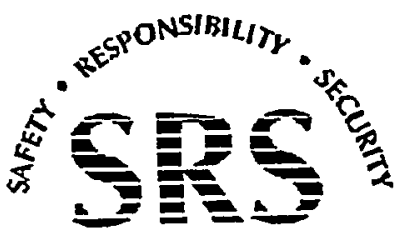


WSRC-TR-2000-00013

Revision 0

Keywords:

Decontamination, High Density,

Assay, Dismantlement, Spectrum, Process Equipment

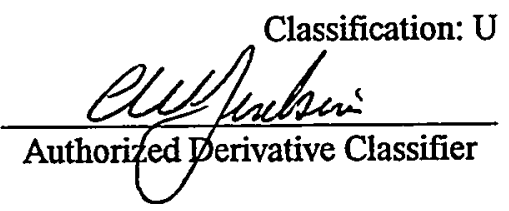

\section{In-Situ $\gamma$-PHA Measurements To Support Unconditional Release}

Of 235-F Chiller Units (U)

Saleem R. Salaymeh, R. A. Dewberry, and John D. Leyba

Publication Date: January 13, 2000

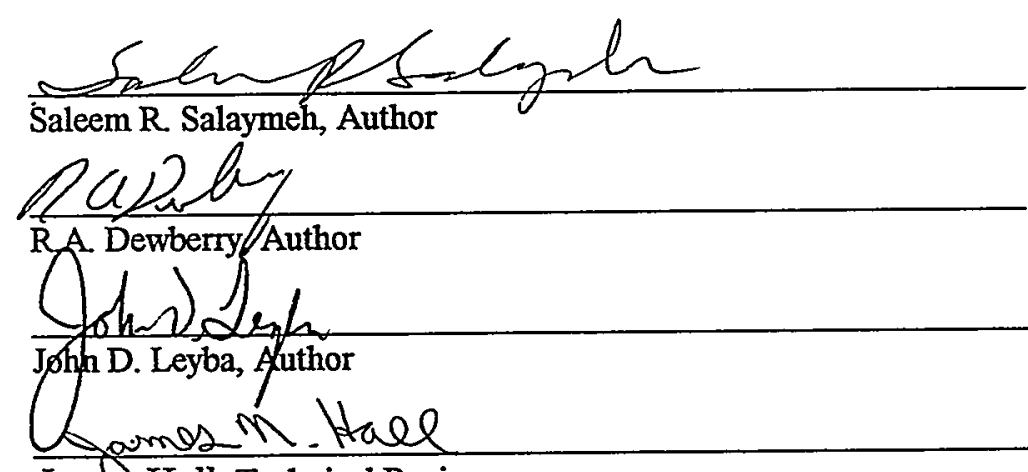

James Hall, Technical Reviewer

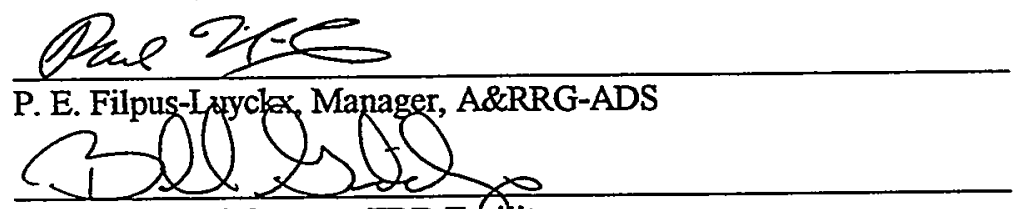

Bill Giddings, Manager, FDD Faeility
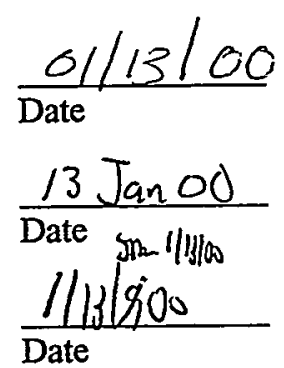

$\frac{1 / 13 / 00}{\text { Date }}$

$1 / 13 / \infty$

Date

$\frac{1 / 3 / 00}{\text { Date }}$

Westinghouse Savannah River Company

Savannah River Site

Aiken, SC 29808

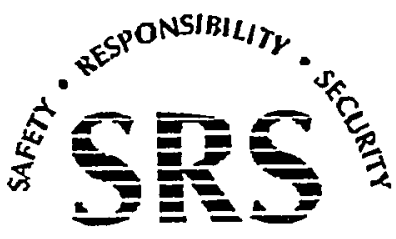




\section{DISCLAIMER}

Portions of this document may be illegible in electronic image products. Images are produced from the best available original document. 


\section{DISCLAIMER}

This report was prepared as an account of work sponsored by an agency of the United States Government. Neither the United States Government nor any agency thereof, nor any of their employees, makes any warranty, express or implied, or assumes any legal liability or responsibility for the accuracy, completeness, or usefulness of any information, apparatus, product or process disclosed, or represents that its use would not infringe privately owned rights. Reference herein to any specific commercial product, process or service by trade name, trademark, manufacturer, or otherwise does not necessarily constitute or imply its endorsement, recommendation, or favoring by the United States Government or any agency thereof. The views and opinions of authors expressed herein do not necessarily state or reflect those of the United States Government or any agency thereof.

This report has been reproduced directly from the best available copy.

Available for sale to the public, in paper, from: U.S. Department of Commerce, National Technical Information Service, 5285 Port Royal Road, Springfield, VA 22161, phone: (800) 553-6847

fax: (703) 605-6900

email: orders@ntis.fedworld.gov

online ordering: http://www.ntis.gov/ordering.htm

Available electronically at http://www.doe.gov/bridge

Available for a processing fee to U.S. Department of Energy and its contractors, in paper, from: U.S. Department of Energy, Office of Scientific and Technical Information, P.O. Box 62, Oak Ridge, TN 37831-0062, phone: (865) 576-8401

fax: (865) $576-5728$

email: reports@adonis.osti.gov 
WSRC-TR-2000-00013

Revision 0

January 13,2000

Page iii of 23

\section{ABSTRACT}

The Analytical Development Section of SRTC was requested by the Facility

Decommission Division (FDD) to conduct in-situ gamma-ray pulse height analysis measurements to support the unconditional release of $235-\mathrm{F}$ chiller units. The chiller units were used to cool process water in the 235-F facility. The measurements' main goal is to confirm that there is no process-related contaminants present on the chillers. For each of the two F-area clean water chillers, we have acquired ten gamma-ray pulse height analysis spectra. All acquisitions were made using a portable system that consists of the following: A portable laptop PC with multichannel analyzer software, A portable cooled germanium detector, EG\&G Dart portable electronics system that contains GammaVision software to support an MCA card, High voltage power, and Space to store and manipulate multiple 4096-channel gamma-ray spectra.

Our results showed no activity above background. All peaks identified in the spectra are due to naturally occurring radionuclides. This confirmed that these chillers are free of process related gamma-emitting radioactive contamination. We estimate the chillers are completely clean of radioactive contamination to the limits of $1 \mathrm{nCi}$ total gamma-ray activity. This report will discuss the purpose of the measurements, the experimental setup, data acquisition, calculations and results, and a conclusion of the study. 
WSRC-TR-2000-00013

Revision 0

January 13, 2000

Page iv of 23

This page intentionally left blank. 
WSRC-TR-2000-00013

Revision 0

January 13,2000

Page $v$ of 23

\section{TABLE OF CONTENTS}

1. INTRODUCTION

2. EXPERMMENTAL …......................................................................................................................8

3. CALCULATIONS OF DETECTION LIMITS................................................................. 10

4. CONCLUSIONS .............................................................................................................................. 12

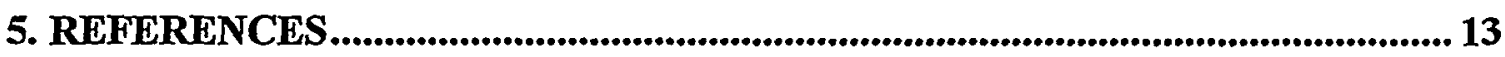


WSRC-TR-2000-00013

Revision 0

January 13, 2000

Page vi of 23

\section{LIST OF FIGURES}

Figure 1. A Photograph of one of the chiller units from 235-F..................................... 8

Figure 2. The grid patterns of the entrance and exit channels ....................................... 9

Figure 3. Field setup showing the close-field configuration.......................................... 10

Figure 4. Background spectrum .................................................................................. 14

Figure 5. Background spectrum with calibration check spectrum.............................. 15

Figure 6. Spectrum of Chiller One Side One Position Three........................................ 16

Figure 7. Net Spectrum of Chiller One Side One Position Three................................. 17

Figure 8. Spectrum of Chiller One Side Two Position Three ....................................... 18

Figure 9. Net Spectrum of Chiller One Side Two Position Three................................. 19

Figure 10. Spectrum of Chiller Two Side One Position Three .................................... 20

Figure 11. Net Spectrum of Chiller Two Side One Position Three............................... 21

Figure 12. Spectrum of Chiller Two Side Two Position Three..................................... 22

Figure 13. Net Spectrum of Chiller Two Side Two Position Three ............................ 23

LIST OF TABLES

Table 1. Measured peak areas in the background spectra ................................................. 13 


\title{
In-Situ $\gamma$-PHA Measurements To Support Unconditional Release Of 235-F Chiller Units (U)
}

\author{
By Saleem R. Sallaymeh, Raymond A. Dewberry, and John D. Leyba \\ Westinghouse Savannah River Company \\ Savannah River Site \\ Aiken SC 29808
}

\section{INTRODUCTION}

The Analytical Development Section (ADS) of SRTC was requested by the Facility Decommission Division (FDD) to conduct in-situ gamma-ray pulse height analysis measurements to support the unconditional release of 235-F chiller units. In early 1998 Construction was tasked to dismantle and replace (D\&R) three chiller units from 235-1F and 235-2F. Each chiller unit is approximately 20 feet long by 3 feet in diameter and contains 100-200 inner copper tubes that run the length of the unit. The outer shell of the units is made of $1 / 2$ inch carbon steel. Figure 1 shows a photograph of one of these units. These units were used to cool process water in the $235-\mathrm{F}$ facility and have been in service for 25 years.

F-Area radiological control organization detected some low-level contamination on one of the chiller units during the D\&R of the old chiller units. Further analysis using a gammaPHA system revealed that there are no low-level concentrations of process derived radionuclides and the activity detected by $\mathrm{RCO}$ was determined to be from naturally occurring radionuclides.

The 235-F Facility assumed the probability of contamination of the units was small and decided to send all three units to the C-Area Decon Facility instead of disposing of them as low level waste. A considerable cost savings can be realized by not sending the units to the low-level burial site. In addition, WSRC Management Policy requires evaluation of treatment and disposal options that consider waste disposal, costs, and risks to dispose of large pieces of equipment rather than the burial option ${ }^{1}$. C-Area Decon Facility proceeded to dismantle the unit that was surveyed in F-Area. During this process, RCO detected some fixed contamination on one of the cover plates, but based on the history of the chillers, this contamination is believed to be naturally occurring.

The Decon Facility wanted to confirm that the remaining two chiller units have no process related contaminants prior to their unconditional release. The plan is to use the history of the units, survey data from the first unit that was completely dismantled, surveys of the accessible areas inside the remaining units, and gamma-PHA to unconditionally release these chillers. Thus, the measurements' main goal is to confirm that there are no processrelated gamma-emitting radioactive contaminants present on the chillers using gammaPHA. 


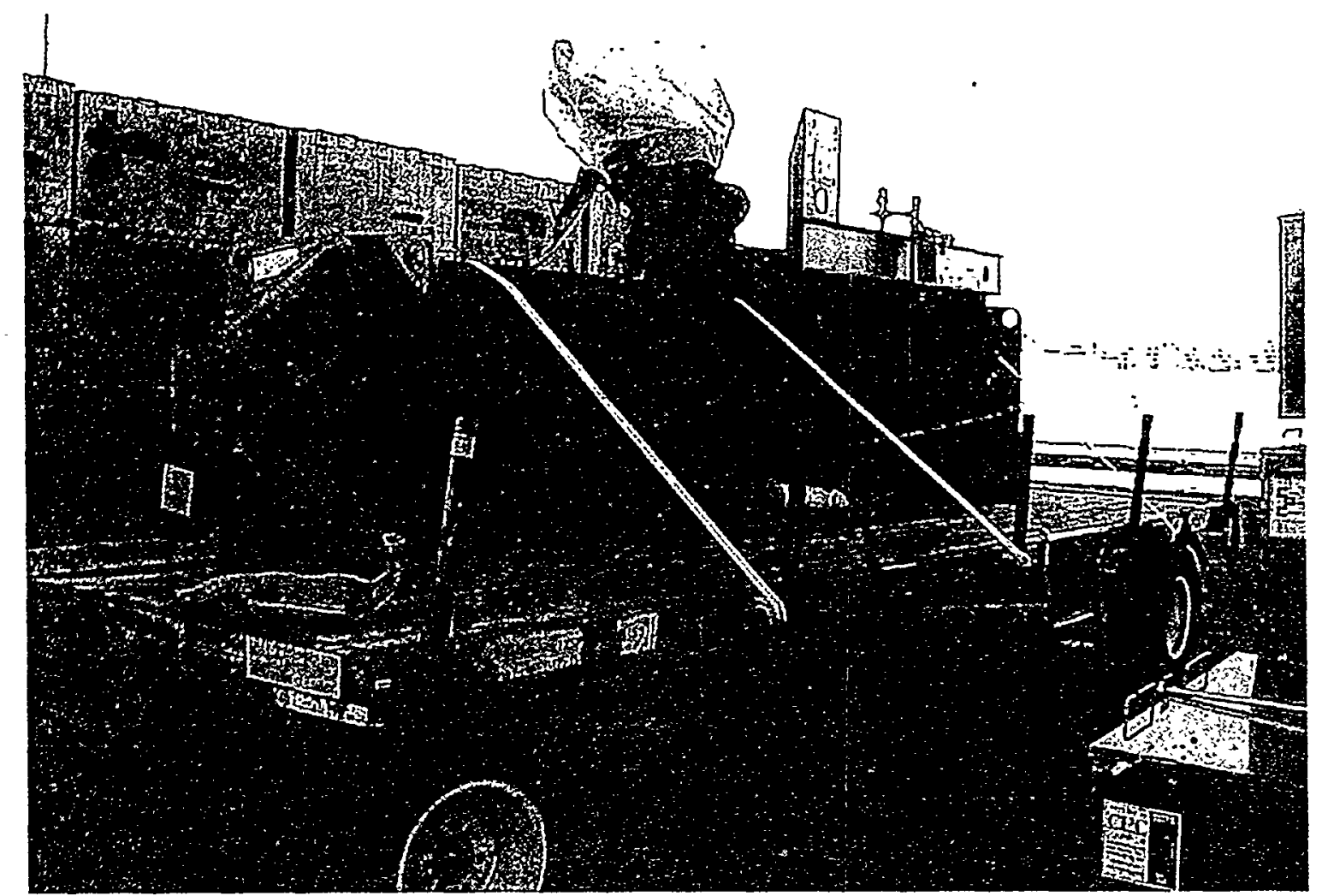

Figure 1. A photograph of one of the chiller units.

\section{EXPERIMENTAL}

Because of the huge mass of the chillers, FDD and the ADS researchers agreed that even a transmission corrected hold-up assay of the chillers would not yield a sensitive measure of activity potentially trapped in the body of the chillers. Together we determined that the entrance and exit ends of the water flow conduits would be the most likely spots where potential activity would be located and could be detected. By removing the chiller end caps it would be possible to obtain a close-coupled assay of the entrance and exit channels.

The grid patterns of the entrance and exit channels shown in Figure 2 yielded a surface that could be approximately treated as a uniform area source of activity. That simplified the measurement and the calculations. 


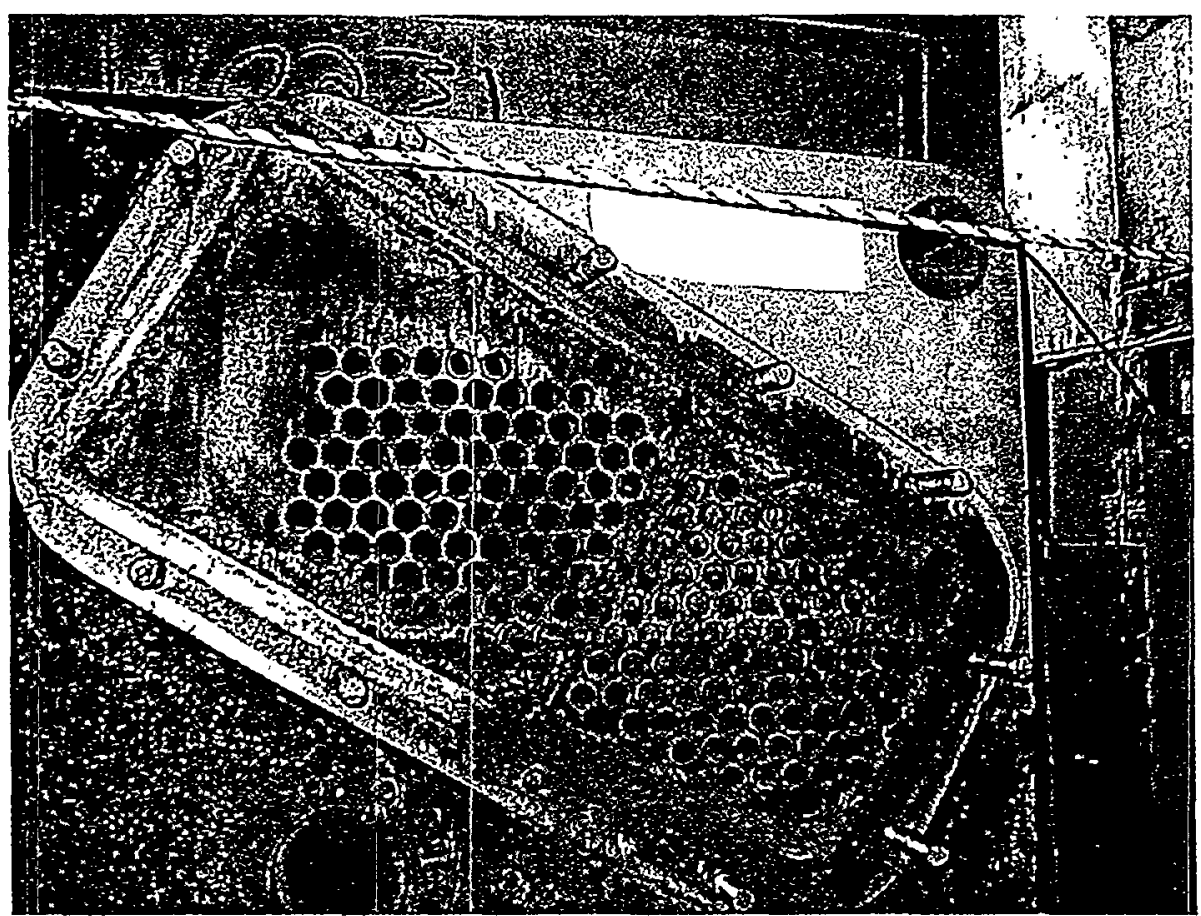

Page 9 of 23

Figure 2. The grid patterns of the entrance and exit channels.

To accomplish the measurements, we set up with the portable EG\&G Dart system that contains GammaVision software to support an MCA card, high voltage power, and space to store and manipulate multiple 4096-channel $\gamma$-ray spectra. We ran with a liquidnitrogen-cooled portable germanium detection system that is described in Technical Report WSRC-TR-99-000396 ${ }^{2}$. We acquired holdup spectra in the close-field configuration as shown in Figure 3. We acquired spectra with the detector approximately 5 inches away from the entrance and exit channels. At that range it was necessary to acquire five spectra from each end of each chiller in order to approximately observe the entire surface area of each end. This yielded a total of twenty spectra.

The measurements for the two chillers were obtained in the Decon Facility of C-reactor building. Since we expected to observe very little activity on the chillers, the local $\gamma$-ray background was a very important quantity. We obtained background spectra with the detector isolated from the chillers by both shielding and distance for the three days on which we acquired data. The background spectrum acquired on December $9^{\text {th }}$ is shown in Figure 4. This spectrum shows several $\gamma$-ray peaks that are labeled on it. The 105-C background $\gamma$-ray activity is composed of natural activity from Th-232 daughters and natural U-238 daughters with additional small contributions from Cs-137 and Co-60. These species would normally be expected in a building that used to be an operating reactor. Using these peaks we were able to energy calibrate the detection system. To confirm our calibration we acquired a second short background with a Cs-137 source hand held next to the detector. This spectrum is shown in Figure 5, and it clearly demonstrates that the Cs-137 $\gamma$-ray at $661.7 \mathrm{keV}$ falls right on target in our calibrated spectrum. 
WSRC-TR-2000-00013

Revision 0

January 13, 2000

Page 10 of 23

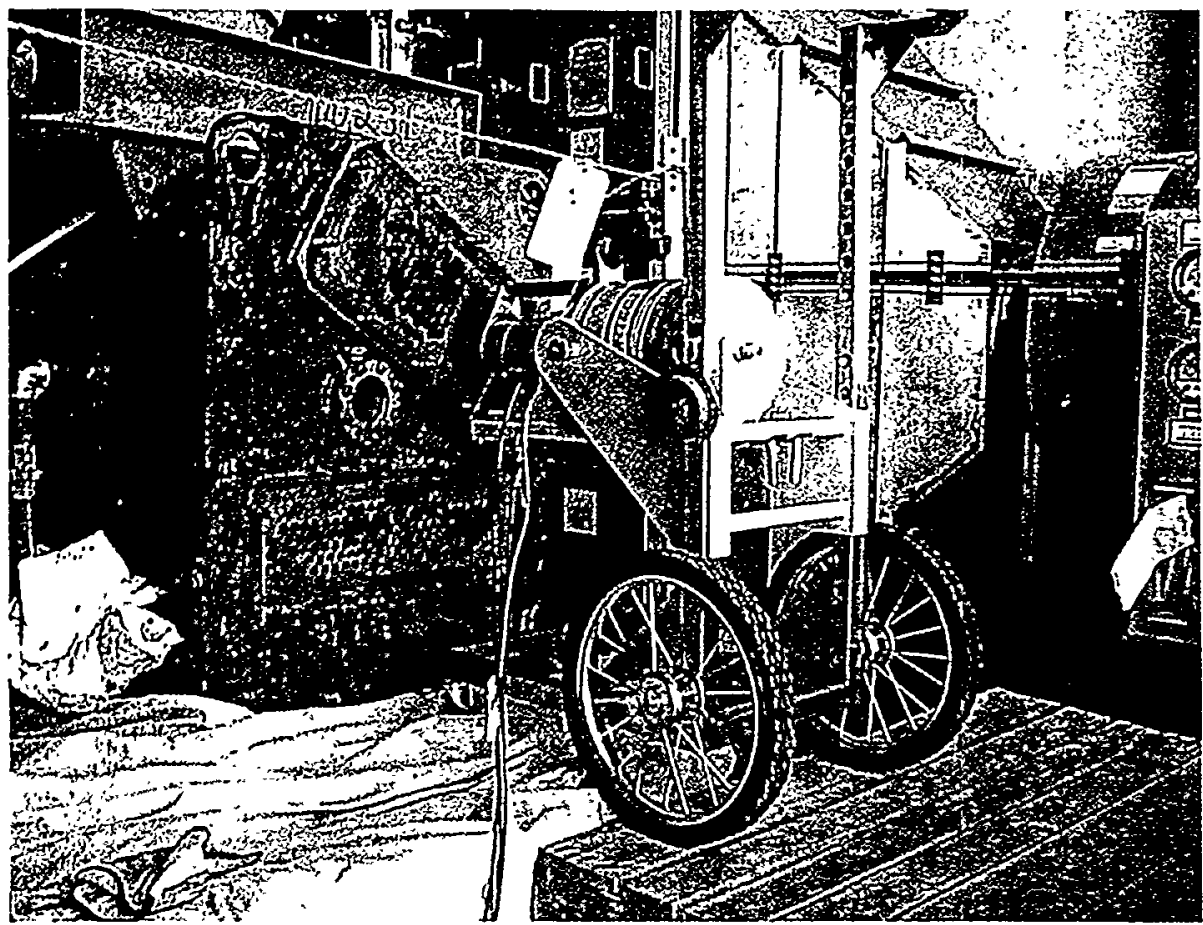

Figure 3. Field setup showing the close-field configuration.

In all of the twenty close-coupled spectra we observed background activity only. Example spectra from both ends of both chillers are shown in Figures 6-13. In those figures we also show the net-stripped spectrum that represents the background-subtracted activity. Note in each net spectrum (Figures $7,9,11$, and 13) that no process-related activity is observed. Therefore in no case is it necessary to calculate measured activity from our close-coupled configuration. It is only necessary to determine limits of detection for those nuclides that are process related. We perform that calculation in the next section.

\section{CALCULATION OF LMMTS OF DETECTION}

Rather than perform a measure of our close-coupled detection efficiency using an area source calibration standard, as a starting point we have used the close-coupled detection efficiency curve that is installed in the high purity germanium (HPGe) detection system in the Analytical Development Section counting room facility of B-003. We have taken this curve and applied two levels of conservatism to be certain our limits of detection are valid. The ADS counting room $\gamma$-PHA system is efficiency checked daily with a Cs-137 QC source. Data for this energy-dependent efficiency curve are documented in Technical Notebook NB-98-00064 on page $14^{3}$. 
The ADS HPGe counting system is a close-coupled finite area source configuration. In our calculations we have assumed that our close-coupled detection efficiency is approximately equal to that of the ADS counting system. Onto the assumption regarding detection efficiencies we have added a second assumption of sample self-absorption. The ADS system assumes no sample self-absorption, while we have assumed a factor of 11 absorption, or conversely a factor of $9 \%$ transmission of $\gamma$-ray activity out of the sample. This is a hugely conservative assumption and is based on U-235 absorption data we acquired on high-density waste in our previous holdup assays in M-Area ${ }^{4}$. In our worstcase high-density waste sample we measured a transmission factor of 3.38 for the U-235 $\gamma$-ray at $185.7 \mathrm{keV}$. To be more conservative still, we have squared that worst case value, $\left([3.38]^{2}=11\right)$ and then applied it to all of the $\gamma$-ray energies of this report - even though the $185.7 \mathrm{keV} \gamma$-ray is the lowest energy photon we consider here.

We finally note the relative intrinsic efficiencies of the HPGe detectors used in the ADS counting room and in these acquisitions. The ADS detector has been measured to have a $28.6 \%$ intrinsic efficiency relative to $\mathrm{NaI}$. The portable detector of this investigation has a measured intrinsic efficiency of $22.3 \%$ relative to NaI. Therefore we have applied this factor of $28.6 / 22.3=1.29$ in all of our calculations.

The data in each background spectrum are shown in Table 1. To calculate the lowerdetection limit (LLD) for each nuclide, we have used five times the standard deviation of the background peak, or simply five times the square root of the number of counts in the background peak. For the U-235 peak at $185.7 \mathrm{keV}$, the limit of detection for chiller one taken on December 9, 1999 is calculated by:

$$
\operatorname{LLD}_{(\mathrm{U}-235)}=[(46)(5)(11)(1.29)(60)] /[(1500)(0.57)(0.0522)(2220)]=2 \mathrm{nCi}
$$

where 46 is the one sigma uncertainty, 5 is the LLD factor defined above, 11 is the transmission factor, 1.29 is the intrinsic efficiency correction factor discussed above, $60 / 1500$ is count time in minutes, 0.57 is the $\gamma$-ray branch, 0.0522 is the detection efficiency, and 2220 is $\mathrm{dpm} / \mathrm{nCi}$.

Collecting constants, $[(5)(11)(1.29)(60)] /[(1500)(2220)]=0.00128$

The Cs-137 limit of detection is then:

$$
\operatorname{LLD}_{(\mathrm{Cs}-137)}=[(0.00128)(22)] /[(0.86)(0.0225)] \quad=\quad 1 \mathrm{nCi} .
$$

The Co-60 detection limit is:

$$
\operatorname{LLD}_{\left(\mathrm{C}_{0}-60\right)}=[(0.00128)(22.5)] /[(0.999)(0.0158)]=2 \mathrm{nCi} .
$$

For the overall $\gamma$-ray limit of detection we use the uncertainty at the $510 \mathrm{keV}$ peak with an assigned branch of 1.000 . 


$$
\begin{aligned}
& \text { WSRC-TR-2000-00013 } \\
& \text { Revision } 0 \\
& \text { January } 13,2000 \\
& \operatorname{LLD}_{\text {(overall) }}=[(0.00128)(29)] /[(1.000)(0.0268)]=1 \mathrm{nCi} .
\end{aligned}
$$

The data acquired on December $14^{\text {th }}$ have different count times and a different background. The combined constant out front is 0.00160 , and

$$
\text { LLD } \quad=\quad[(0.00160)(\text { uncert })] /[\text { (branch) }(\text { eff. })] .
$$

Even though the acquisition time of December $14^{\text {th }}$ was shorter than that of December $9^{\text {th }}$, we obtained lower uncertainties in the fitted background. Therefore the December $14^{\text {th }}$ limits of detection are smaller than those obtained on December $9^{\text {th }}$. For U-235 the limit of detection is:

$$
\operatorname{LLD}_{(\mathrm{U}-235)}=[(0.00160)(28)] /[(0.57)(0.0522)]=2 \mathrm{nCi}
$$

For Cs-137 the lower limit of detection is:

$$
\operatorname{LLD}_{(\mathrm{Cs}-137)}=[(0.00160)(13)] /[(0.86)(0.0225)]=1 \mathrm{nCi}
$$

The Co-60 detection limit is:

$$
\operatorname{LLD}_{\left(\mathrm{C}_{0}-60\right)}=[(0.00160)(14)] /[(0.999)(0.0158)] \quad=\quad 1 \cdot \mathrm{nCi}
$$

For the overall $\gamma$-ray limit of detection we use the uncertainty at the $510 \mathrm{keV}$ peak with an assigned branch of 1.000 .

$$
\operatorname{LLD}_{\text {(overall) }}=[(0.00160)(19.5)] /[(1)(0.0268)] \quad \cdot \quad=\quad 1 \mathrm{nCi} .
$$

The background, data, and limits of detection acquired on the separate dates are in good agreement.

\section{CONCLUSION}

ADS researchers have acquired close coupled $\gamma$-PHA spectra from ten distinct points on two 235-F water chillers and have been able to set lower limits of detection for Co-60, $\mathrm{Cs}-137, \mathrm{U}-235$, and total $\gamma$-ray activity on the chillers. In the $\gamma$-ray spectra that were obtained in the C-Area Decon Facility only naturally occurring $\gamma$-ray transitions from the U-238 decay chain and from the Th-232 decay chain were observed. Using a special setup with conservative assumptions, the researchers have been able to set upper limits of content for potential gamma-emitting contamination that allows free release of the chillers.

Table 1 lists the measured peak areas in the background spectra acquired December $9^{\text {th }}$ and December $14^{\text {th }}$. The December $9^{\text {th }}$ background is a 1500 -second acquisition and the December $14^{\text {th }}$ background is a 1200 -second acquisition. The tabulated peak areas are in units of total counts, and the values in parentheses are the 2-sigma uncertainties. 
WSRC-TR-2000-00013

Revision 0

January 13,2000

Page 13 of 23

Table 1. Measured peak areas in the background spectra

\begin{tabular}{|c|c|c|c|c|c|}
\hline & $\begin{array}{l}186 \mathrm{keV} \\
\text { U-235 }\end{array}$ & $\begin{array}{l}238 \mathrm{keV} \\
\text { Tl-208 }\end{array}$ & $\begin{array}{l}510 \mathrm{keV} \\
\text { Tl-208 }\end{array}$ & $\begin{array}{l}662 \mathrm{keV} \\
\text { Cs-137 }\end{array}$ & $\begin{array}{l}1173 \mathrm{keV} \\
\mathrm{Co}-60\end{array}$ \\
\hline Bkg 12/9/99 & $-39(92)$ & $375(95)$ & $288(58)$ & $270(44)$ & $328(45)$ \\
\hline Bkg 12/14/99 & $-84(56)$ & $183(79)$ & $172(39)$ & $144(28)$ & $128(26)$ \\
\hline
\end{tabular}

\section{REFERENCES}

1. WSRC Manual 1-01, Management Policies, Policy 5.30, "Disposition of Contaminated Large Equipment," Revision No. 0, September 30, 1996.

2. R. A. Dewberry and S. R. Salaymeh, 'U-235 Holdup Measurements of Mixed Waste at SRS (U), WSRC-TR-99-00396, October 1999.

3. R. A. Dewberry "Nuclear Radiochemistry Research Notebook", WSRC-NB-98-. 00064, February 1998.

4. R. A. Dewberry, F. S. Moore, and S. R. Salaymeh, "Confirmatory Assays of M-Area Solid Waste", SRT-ADS-98-578, November 1998. 


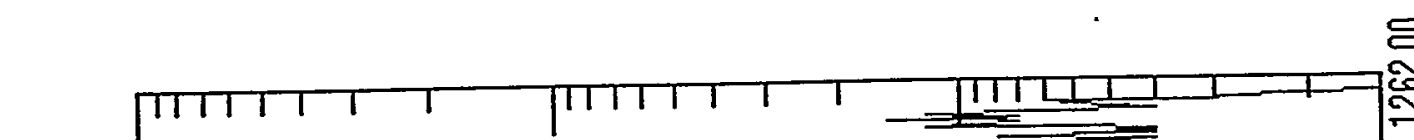

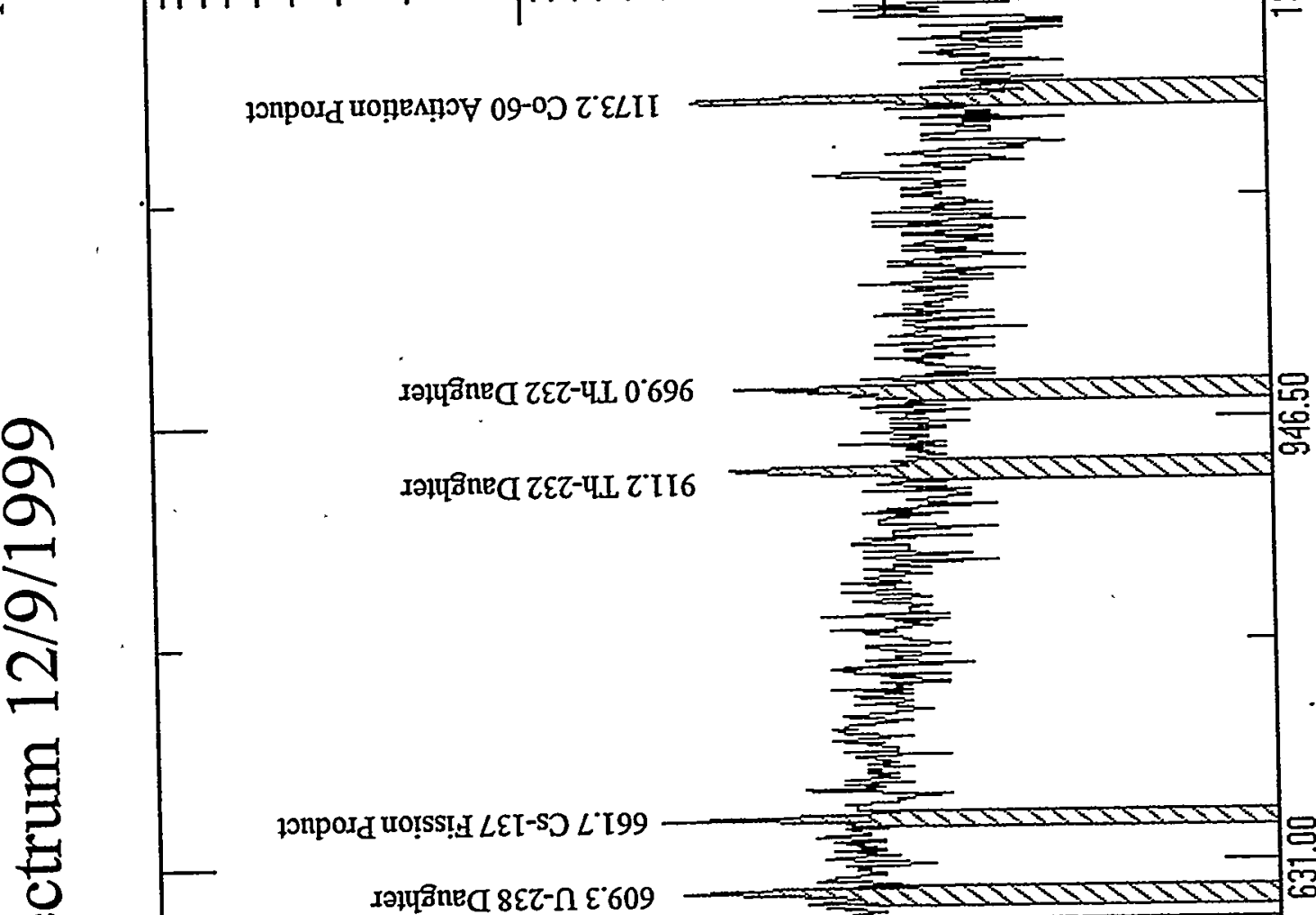

(1)

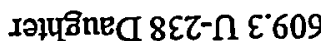

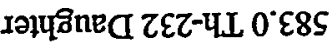

总

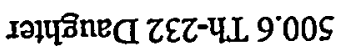

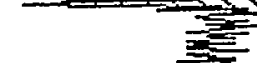




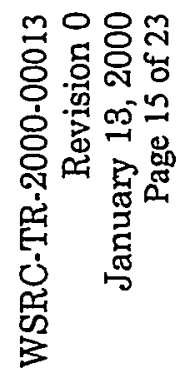

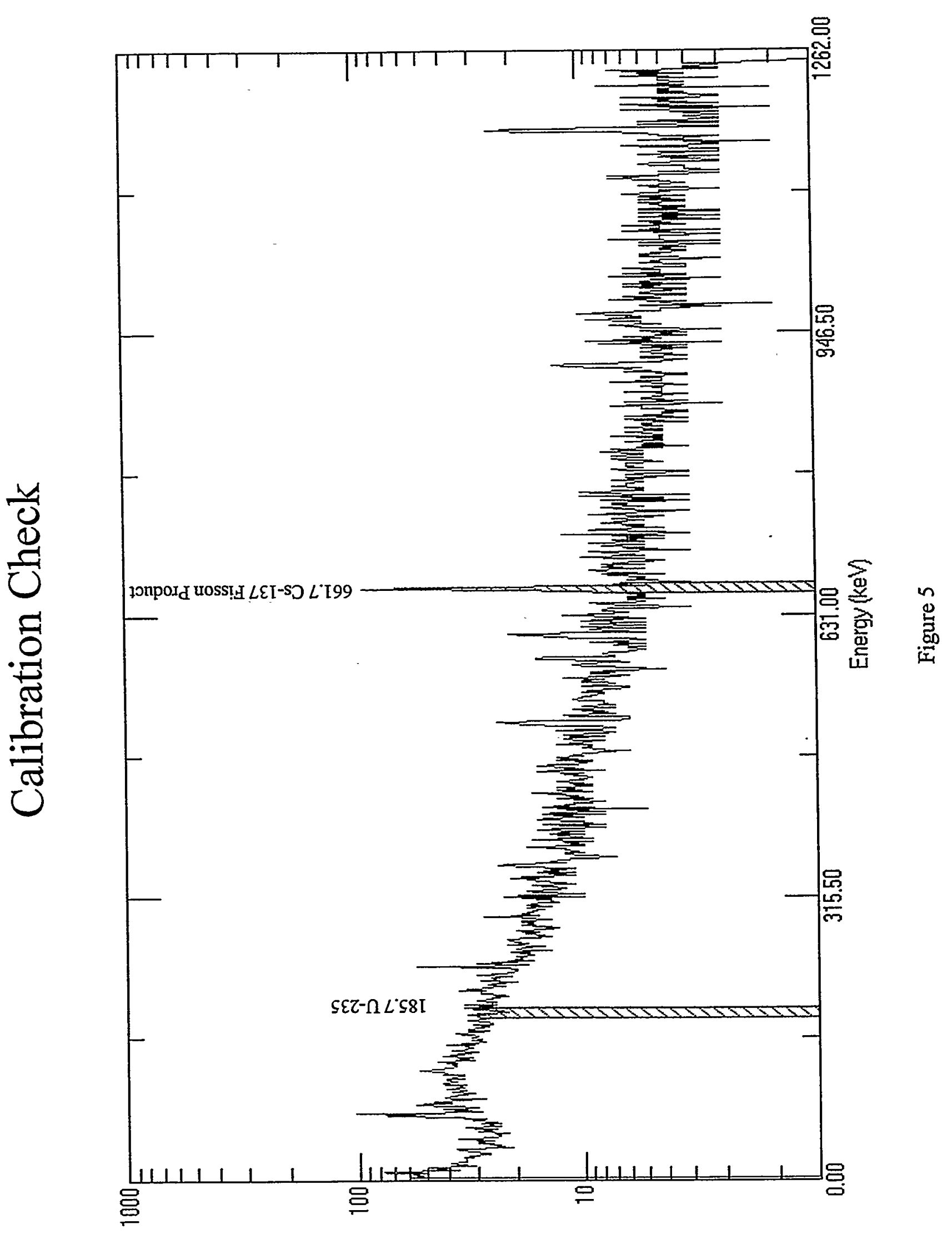

sfunoo 

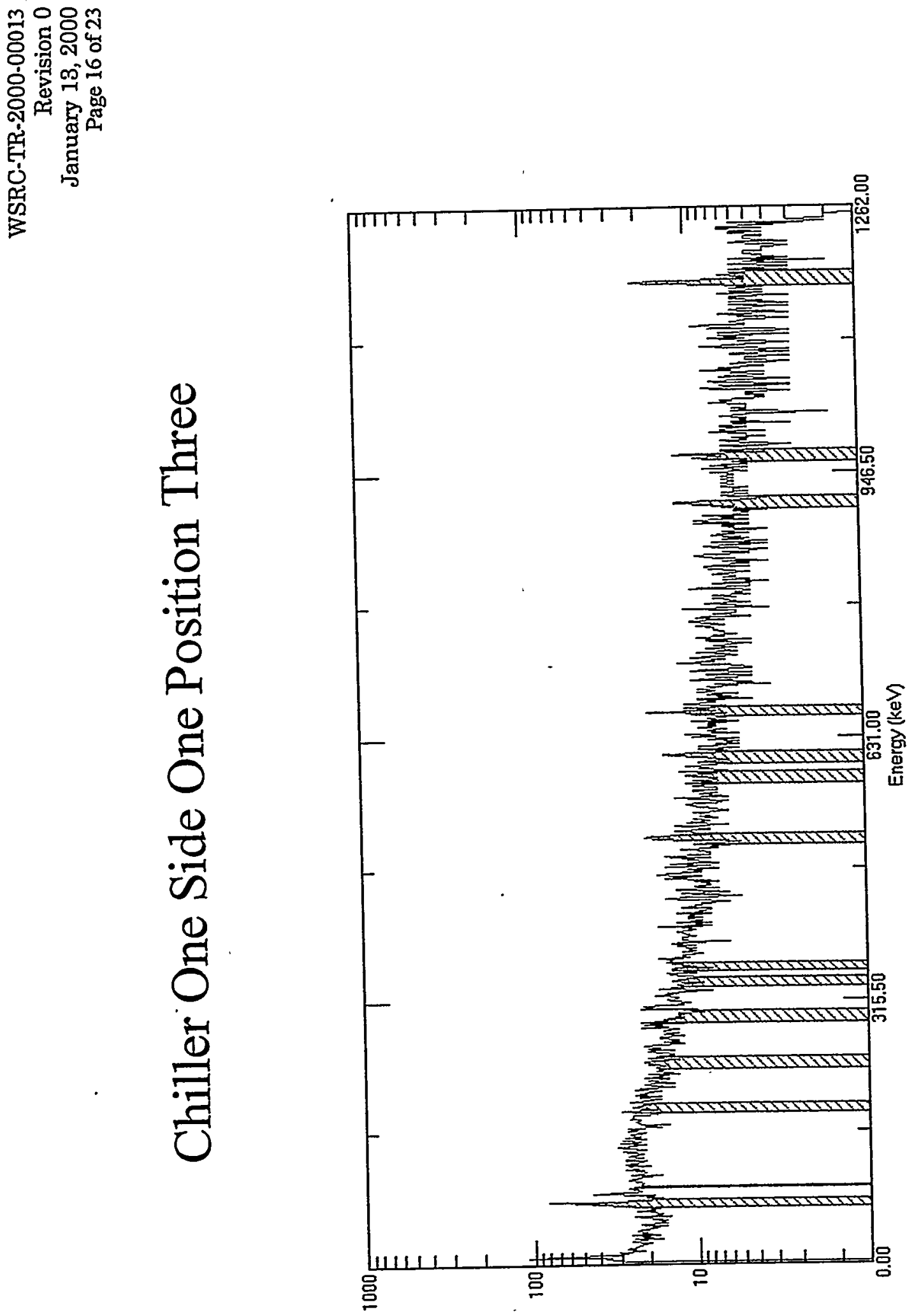

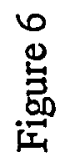

słunoว 

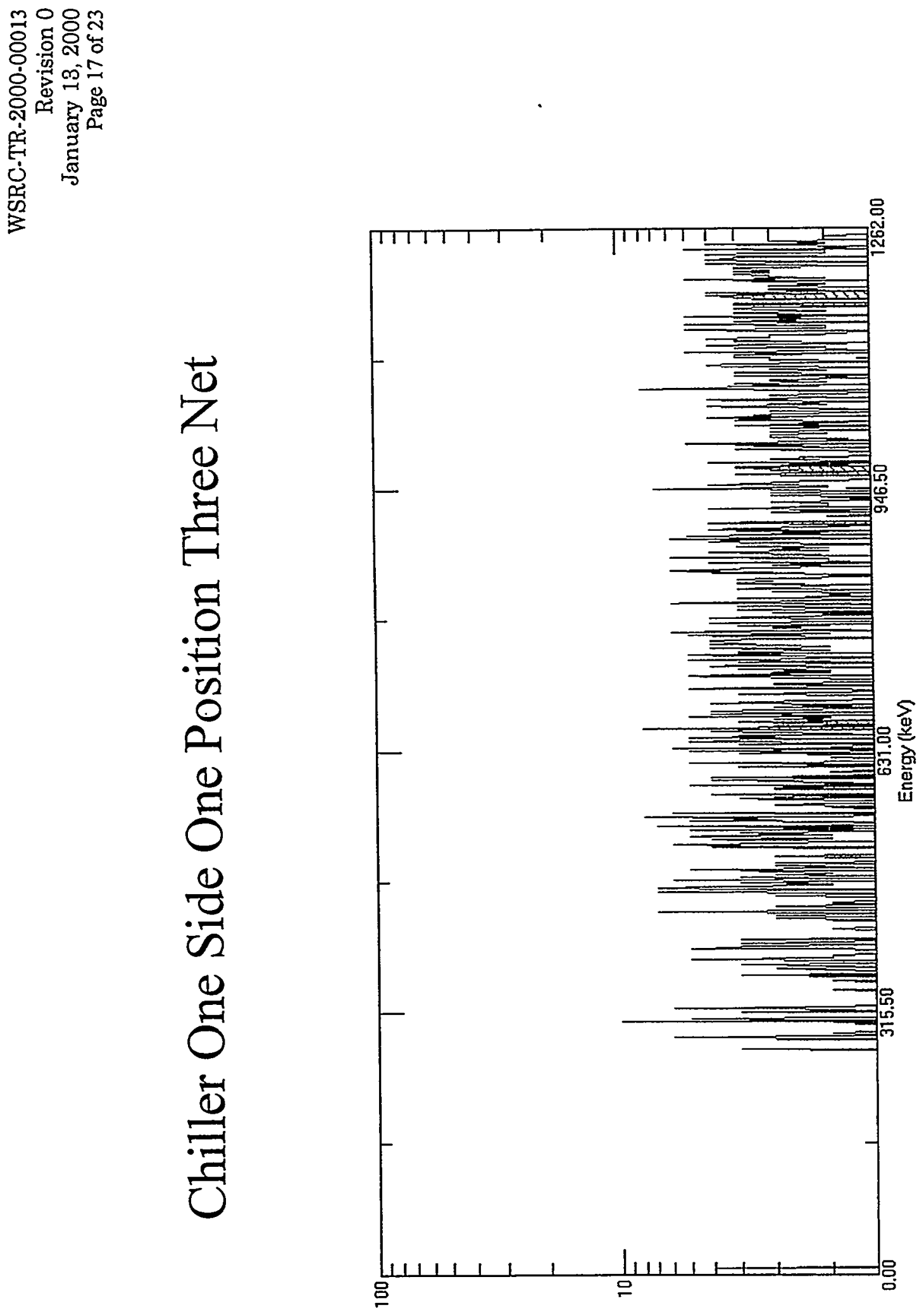

${ }_{0}^{\infty}$

squno? 

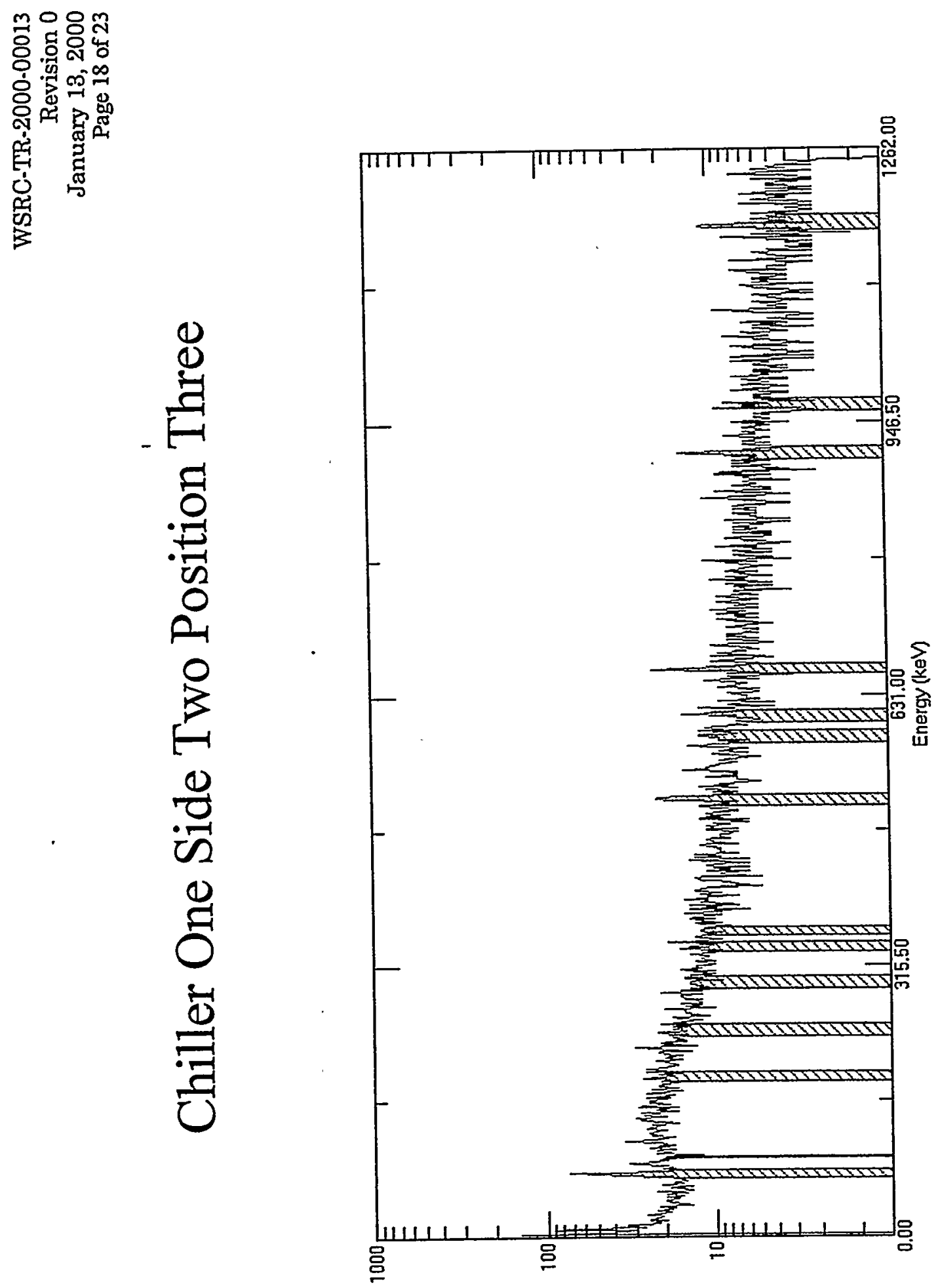

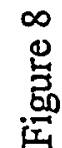

squnos 

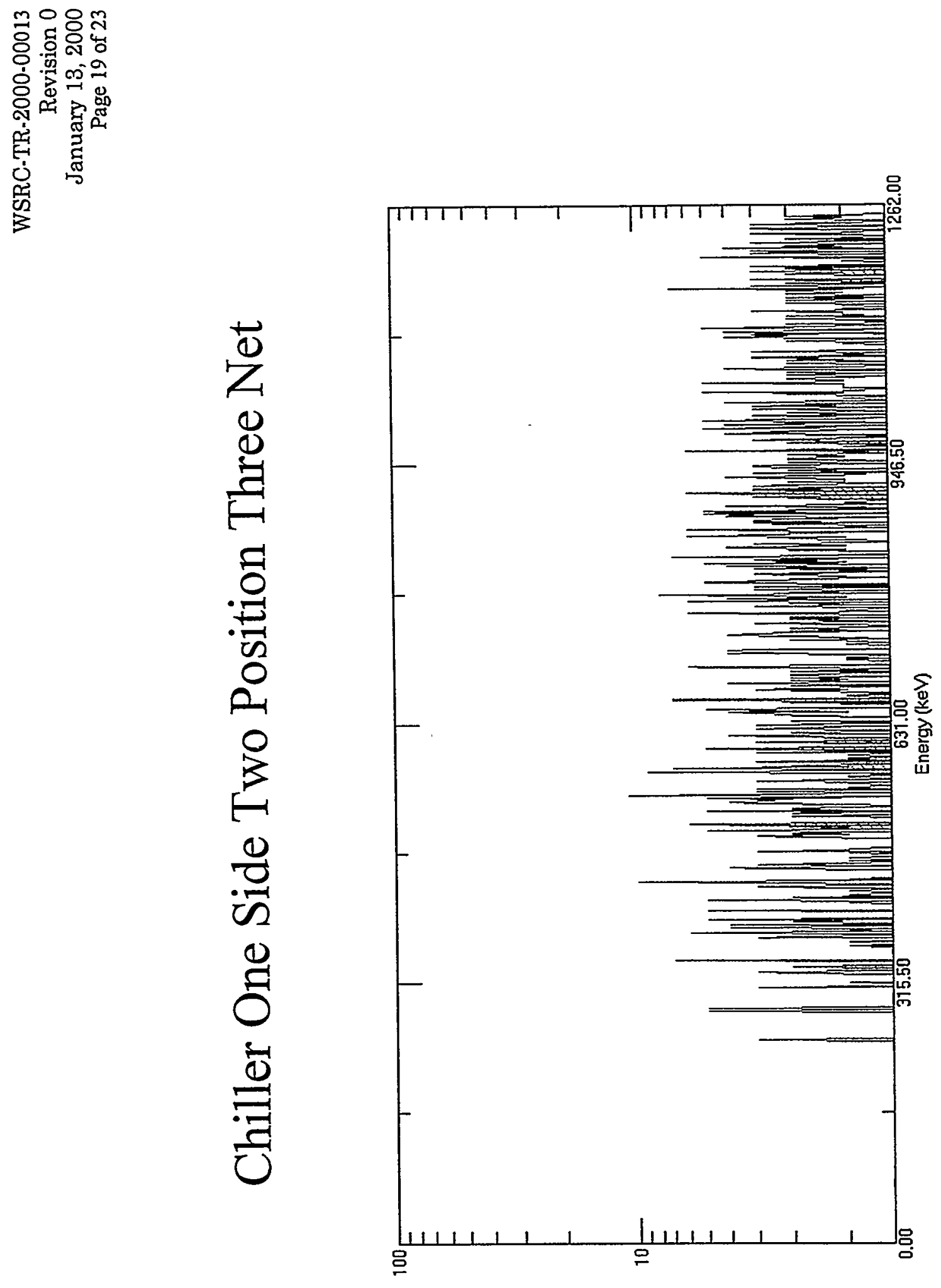

a

słunoว 

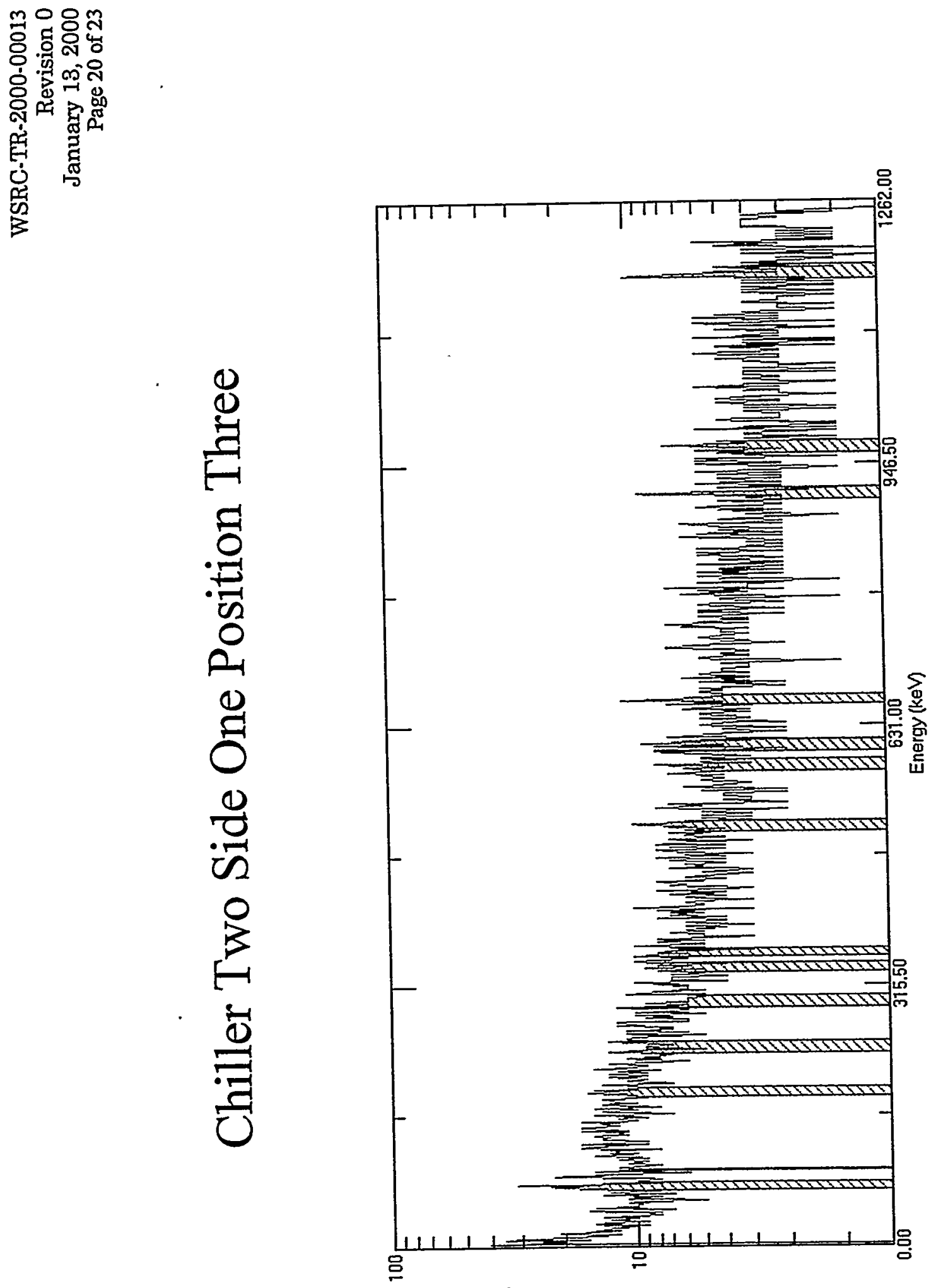

옹

squnos 


\section{Chiller Two Side One Position Three Net}

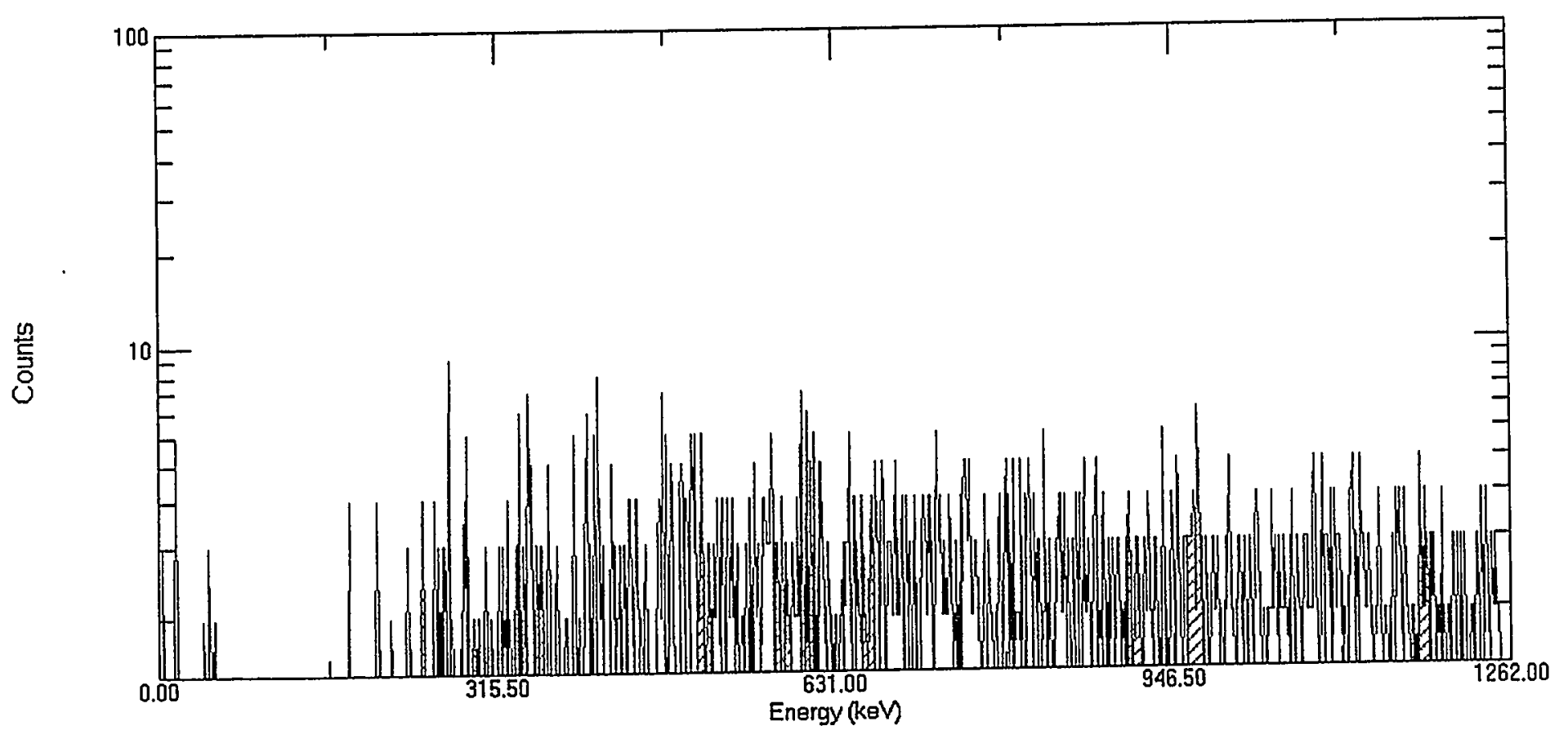

Figure 11 

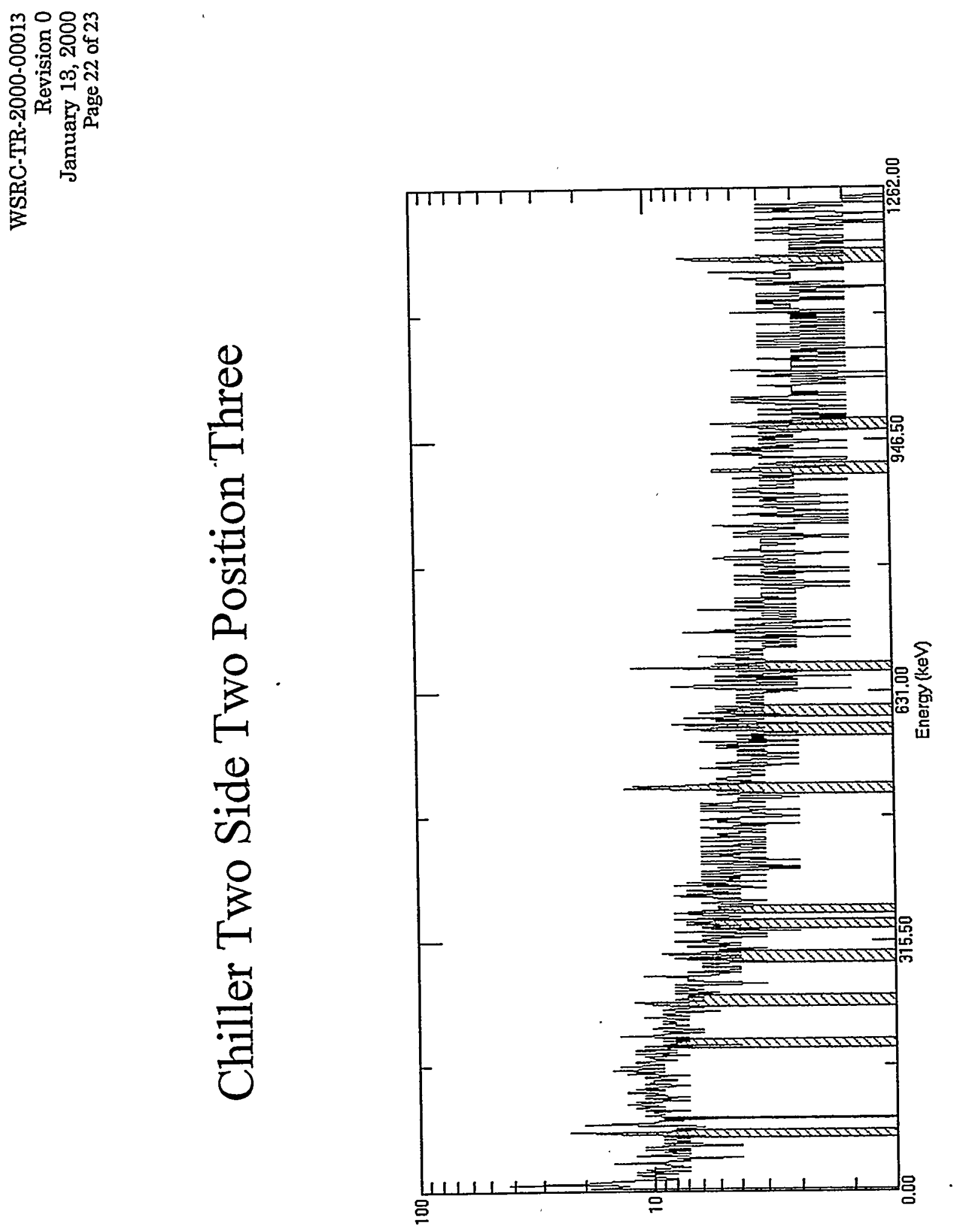

$\stackrel{ }{ \pm}$

squnos 

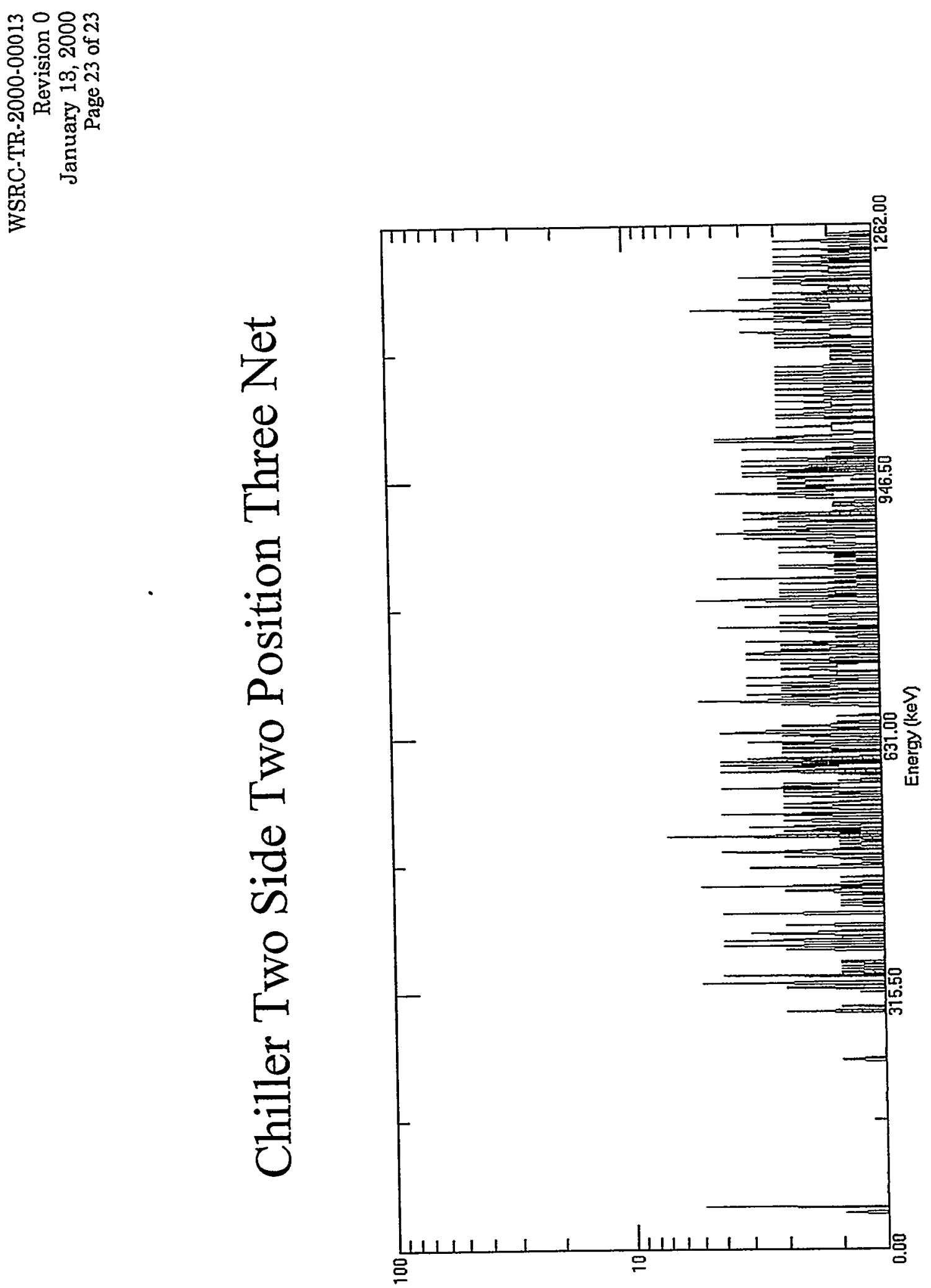

$\stackrel{n}{\stackrel{m}{0}}$ 